\title{
THE POLICY OF OVERCROWDING MANAGEMENT OF JAIL IN INDONESIA DURING COVID-19 PANDEMIC
}

\section{KEBIJAKAN MENANGANI OVERCROWDING DI INDONESIA PADA MASA PANDEMI COVID-19*}

\author{
Rudini Hasyim Rado ${ }^{1}$, Nurul Widhanita Yuniar Badilla ${ }^{2}$ \\ Fakultas Hukum, Universitas Musamus, \\ Jl. Kamizaun Mopah Lama Merauke 99611 \\ "e-mail: rado_fh@unmus.ac.id ${ }^{1}$ \\ e-mail: badila_hukum@unmus.ac.id ${ }^{2}$
}

\begin{abstract}
This research is focused on the overcrowding management policy of jail capacity in Indonesia by utilizing coronavirus disease (covid-19) pandemic momentum. The method of the research is an empiric juridical law method and other related laws and regulations as the primer data confirmed with the observation. Data analysis of the research is based on descriptive analysis. Based on the research data, it might be concluded that the situation in the prisons before the covid19 pandemic was nationally overcrowding in $102 \%$ and it occurred almost all over Indonesia. This overcrowding condition was overloaded and inhuman, moreover in the covid-19 pandemic period. It potentially transmits the disease to the prisoners and officers, thus assimilation policy had been applied by intention to release 40.026 prisoners. It decreases the overcrowding percentage to be 74\%. On the other side policy restriction for particular crimes might provide more spaces in the prisons, even though it is hard to be considered effective because overcrowding is still existed.
\end{abstract}

Keywords: Overcrowding; Policy; Covid-19.

\begin{abstract}
Abstrak
Penelitian ini difokuskan pada kebijakan menangani overcrowding (kelebihan penghuni) di rutan/lapas Indonesia memanfaatkan momentum pencegahan pandemi covid-19. Penelitian ini menggunakan metode penelitian hukum yuridis empiris dengan peraturan perundang-undangan terkait sebagai data primer didukung dengan observasi. Sedangkan analisis data bersifat deskriptif analitis. Disimpulkan bahwa situasi rutan/lapas sebelum covid-19 mengalami overcrowding nasional diangka $102 \%$ serta terjadi hampir merata di seluruh Indonesia. Kondisi overcrowding yang penuh dan sesak saja sudah tidak manusiawi apalagi terjadi di tengah pandemi covid-19 yang berisiko menular ke penghuni maupun petugas sehingga ditempuh kebijakan asimilasi dan hak integrasi dengan membebaskan setidaknya 40.026 narapidana, sehingga berdampak pada penurunan overcrowding diangka $74 \%$, namun disisi lain adanya pembatasan kebijakan yang hanya ditujukan terhadap kejahatan tertentu sekalipun memberikan kelonggaran pada rutan/lapas namun masih sulit dikatakan efektif karena sesungguhnya situasi overcrowding tetap berlangsung.
\end{abstract}

Kata Kunci: Overcrowding; Kebijakan; Covid-19.

\footnotetext{
* Naskah diterima: 9 Februari 2021, direvisi: 10 Maret 2021, disetujui untuk terbit: 27 Maret 2021

Doi: $10.3376 /$ jch.v6i2.332
} 


\section{PENDAHULUAN}

Setiap kebijakan hukum, tujuan bernegara seharusnya menjadi acuan utama yang harus dipikirkan oleh pengambil kebijakan. Tujuan yang telah digariskan dalam Pembukaan UUD NRI Tahun 1945 itu secara singkat ialah "melindungi segenap bangsa Indonesia dan untuk memajukan kesejahteraan umum berdasarkan Pancasila". Inilah garis kebijakan umum yang wajib dicapai dalam konteks bernegara (Alin, 2017).

Setiap kebijakan hukum, tujuan tersebut harus menjadi patokan. Jangan sampai kebijakan hukum hanya sematamata untuk memenuhi dahaga efek jera. Hukum termasuk hukum pidana, tentu saja dapat digunakan sebagai sarana mengubah masyarakat namun hal itu harus dilakukan secara rasional dan sistematis. Dimulai dengan mengenali masalah sebaik-baiknya termasuk mengenali masyarakat sebagai sasaran sampai dengan mengikuti jalannya penerapan hukum termasuk dampak yang dihasilkan (Novian et al., 2018).

Salah satu dampak dari kebijakan hukum pidana yang paling terlihat jelas adalah penggunaan pidana penjara yang berlebihan. Hal ini merupakan asumsi dasar bahwa penggunaan pidana penjara termasuk upaya penahanan yang dikenakan terhadap tersangka/terdakwa sangat berguna untuk membuat efek jera. Persoalannya, dampak ikutan dari upaya penanggulangan kejahatan melalui sarana penjara tidak dipikirkan secara serius (Novian et al., 2018).
Permasalahan yang terjadi saat ini akibat orientasi penerapan hukum pidana yang berkiblat pada penjara menghasilkan situasi overcrowding. Adapun overcrowding yang dimaksud di sini adalah situasi krisis akibat kepadatan atau kelebihan jumlah penghuni (narapidana dan/atau tahanan) pada rutan/lapas daripada jumlah kapasitas/ruang yang tersedia. Situasi overcrowding menempatkan Indonesia pada titik ekstrim dengan kelebihan penghuni presentasi nasional sebesar 102\% (Pemasyarakatan, 2020b). Orientasi demikian menjadi bertolak belakang dengan ide dan tujuan pembinaan yang dilakukan menjadi tidak optimal bahkan dapat menuju pada kegagalan fungsi pembinaan. Dikatakan demikian, karena situasi ini membuat munculnya berbagai masalah dari rendahnya pemenuhan hak-hak tahanan dan narapidana, minimnya sarana prasarana, kaburnya tahanan dan narapidana, dan berbagai permasalahan lainnya.

Sewaktu terjadi overcrowding saja sudah tidak manusiawi, apalagi hal ini terjadi bersamaan di saat pemerintah sedang menghadapi bencana nasional non alam yaitu penyebaran pandemi coronavirus disease (covid-19). Virus covid-19 merupakan penyakit menular yang disebabkan oleh jenis coronavirus yang dapat menyebabkan penyakit pada hewan atau manusia. Covid-19 dapat menyebar terutama dari orang ke orang melalui percikan-percikan dari hidung atau mulut yang keluar saat orang terinfeksi covid-19 (WHO, 2020). Virus 
dengan tingkat penyebaran sangat cepat serta sangat menyukai karakteristik ruang gelap, sempit dan dipenuhi kerumunan orang baik penghuni (tahanan/narapidana) maupun petugas keamanan seperti di rutan/lapas. Situasi mana perlu mendapat perhatian serius dari pemerintah tidak hanya mengurangi overcrowding melainkan sekaligus memutus mata rantai penyebaran covid-19 untuk menghindarkan rutan/lapas berubah menjadi kuburan massal akibat wabah covid-19.

Merespon $\begin{gathered}\text { kondisi } \\ \text { demikian, } \\ \text { pemerintah mengeluarkan formula } \\ \text { kebijakan melalui Menteri Hukum dan }\end{gathered}$
Hak Asasi Manusia, berupa program asimilasi dan hak integrasi dalam rangka mencegah dan menanggulangi penyebaran covid-19, hal mana sekaligus mengonfirmasi maksud lain daripada menangani overcrowding di Indonesia yang sedemikian memprihatinkan. Penelitian ini bertujuan untuk mengkaji situasi overcrowding di Indonesia dan menelaah kebijakan negara dalam menangani overcrowding pada masa pandemi covid-19. Maka dari itu, rumusan masalah yang hendak disuguhkan pada penulisan ini adalah pertama, terkait bagaimana situasi overcrowding di Indonesia pra pandemi covid-19? Kedua, bagaimana kebijakan menangani overcrowding di Indonesia pada masa pandemi covid-19?

\section{METODE PENELITIAN}

Dilihat dari jenisnya penelitian ini termasuk ke dalam jenis penelitian hukum yuridis empiris. Data yang digunakan dalam penelitian ini berasal dari sumber hukum primer yang terdiri dari data primer dan sekunder. Data primer terdiri dari peraturan perundang-undangan yang sesuai konteks dan didukung studi lapangan berupa observasi terkait dengan situasi overcrowding di rutan/lapas di Indonesia pada masa pandemi. Data sekunder berupa buku, jurnal, makalah, hasil-hasil penelitian, karya ilmiah dan sumber informasi dari internet yang berkaitan penanganan overcrowding. Adapun spesifikasi penelitian ini termasuk lingkaran penelitian deskriptif analitis karena merupakan suatu upaya untuk mendeskripsikan (mengungkapkan dan memaparkan) situasi overcrowding yang terjadi di lapas/rutan di Indonesia pada masa pandemi, yang selanjutnya dianalisis menggunakan metode kualitatif. Cara pengolahan dilakukan secara deduktif yakni menarik kesimpulan dari suatu permasalahan yang bersifat umum terhadap permasalahan yang konkrit.

\section{HASIL DAN PEMBAHASAN}

\section{A. Situasi Overcrowding di Indonesia Pra Pandemi Covid-19}

Penanggulangan kejahatan dengan menggunakan sanksi pidana merupakan cara yang paling tua, setua peradaban manusia itu sendiri. Ada pula yang menyebutnya sebagai order philosophy of crime control (Arief, 2010). Dan salah satu jenis sanksi pidana yang paling sering digunakan untuk menanggulangi kejahatan ialah pidana penjara sejak akhir abad 18 yang bersumber dari paham individualisme dan gerakan kemanusiaan 
untuk menggeser kedudukan pidana mati dan pidana badan yang dipandang kejam.

Penggunaan upaya hukum, termasuk sanksinya yang berupa pidana penjara. Usaha ini pun masih sering dipersoalkan, kritik dilontarkan pada umumnya dengan dalih pidana penjara selain menimbulkan dampak negatif dengan dirampasnya kemerdekaan juga berkaitan dengan cap jahat (stigma). Adanya gelombang kritik tersebut, dilakukanlah usaha mencari bentuk-bentuk alternatif dari pidana penjara, namun demikian diakui juga bahwa pidana penjara tidak dapat dibuang secara keseluruhan. Tepatlah pendapat Sudarto bahwa "orang memang sudah lama tidak menyukai pidana itu, akan tetapi tidak dapat meninggalkannya sama sekali, karena ia tidak tahu bagaimana harus menggantinya" (Sudarto, 2010).

Rutan dan lapas merupakan fasilitas yang digunakan oleh negara untuk melakukan penahanan bagi tersangka/terdakwa dan narapidana dalam tahapan penegakan hukum. Rutan diperuntukkan bagi tahanan (tersangka/terdakwa) yang harus di tahan selama proses penyidikan, penuntutan dan pemeriksaan di sidang pengadilan di Indonesia. Sedangkan lapas adalah tempat untuk melaksanakan pembinaan narapidana dan anak pemasyarakatan di Indonesia.

Sejak beberapa tahun terakhir, kondisi kedua fasilitas yang mengalami overcrowding telah mencapai titik yang memprihatinkan.

Overcrowding rutan/lapas merupakan permasalahan yang masih sulit diatasi. Situasi ini disadari betul oleh Menteri Hukum dan Hak Asasi Manusia (Menkumham), Yasonna H. Laoly, dikatakan olehnya, jika trend tersebut terus menerus terjadi tanpa ada suatu perubahan besar, diperkirakan ke depan akan terjadi "bom waktu". Pernyataan demikian bukan tanpa alasan dikarenakan jumlah penghuni yang terus bertambah sedangkan kapasitas hunian sangat terbatas. Kapasitas hunian di seluruh Indonesia hanya ditujukan bagi 133.069 penghuni, namun dihuni oleh 268.922 penghuni. Artinya terjadi selisih mencapai angka 135.853 atau $102 \%$ over population (Pemasyarakatan, 2020b).

Bahkan, peningkatan jumlah ini tidak sebanding dengan fasilitas dan daya tampung hunian pada rutan/lapas. Berikut merupakan gambaran sebaran jumlah penghuni (tahanan/narapidana) dibandingkan jumlah rutan/lapas di Indonesia tahun 2016 sampai dengan Februari 2020, selengkapnya sebagai berikut:

Tabel 1 : Tingkat Overcrowding Tahun 2016-Februari 2020

\begin{tabular}{cccccc}
\hline \multirow{2}{*}{ No. } & \multirow{2}{*}{ Tahun } & \multicolumn{4}{c}{ Tingkat Overcrowding } \\
& & $\mathrm{n}^{*}$ & $\mathrm{k}^{*}$ & $\mathrm{~s}$ & $\%$ \\
\hline 1. & 2016 & 204.551 & 119.797 & 84.754 & 78 \\
2. & 2017 & 232.081 & 123.481 & 108.600 & 88 \\
3. & 2018 & 236.877 & 123.564 & 113.313 & 91 \\
4. & 2019 & 265.648 & 133.069 & 132.579 & 100 \\
5. & 2020 & 268.922 & 133.069 & 135.853 & 102 \\
\hline
\end{tabular}


*) $\mathrm{n}=$ jumlah; $\mathrm{k}=$ kapasitas; $\mathrm{s}=$ selisih

Sumber : Sistem Database Pemasyarakatan (SDP, Dirjen Pemasyarakatan.

Dapat dilihat dari tabel di atas, jumlah tahanan/narapidana setiap tahun mengalami peningkatan, jika dicermati terjadi penambahan kapasitas hunian 2019 dibandingkan tahun sebelumnya. Meskipun demikian, kondisi tersebut tidak menjawab dan menyelesaikan permasalahan kelebihan hunian yang terjadi. Adanya presentasi overcrowding yang meningkat tiap tahunnya dikarenakan jumlah total tahanan dan narapidana juga mengalami peningkatan yang cukup signifikan. Apabila di bulan Maret 2020, presentasi nasional overcrowding sebesar 102\%, namun untuk wilayah Kalimantan Timur angkanya bahkan mencapai $253 \%$, diikuti Jakarta 217\% dan Riau 201\%. ${ }^{1}$ Hanya empat Provinsi yang tidak mengalami overcrowding adalah Yogyakarta, Gorontalo, Maluku Utara, dan Sulawesi Barat. Dapat disimpulkan bahwa dari 33 wilayah Kemenkumham overcrowding terjadi nyaris merata di seluruh Indonesia.

Situasi overcrowding di rutan/lapas seluruh Indonesia ini akan mengakibatkan beberapa masalah. Pertama, program pembinaan (pembinaan kerja dan keterampilan, rehabilitasi medis dan sosial) tidak berjalan dengan baik karena jumlah penghuni yang terlalu banyak. Kedua, minimnya pemenuhan hak-hak penghuni berupa fasilitas tempat tinggal tidak memadai, sanitasi yang bersih,

\footnotetext{
1 Istilah overcrowding untuk occupancy rate di atas $100 \%$, critical overcrowding untuk occupancy rate di atas $120 \%$, dan extreme overcrowding untuk occupancy rate di atas $150 \%$.
}

layanan kesehatan dan nutrisi sampai problem penyebaran penyakit menular serta pemenuhan bahan makanan. Tercatat pada tahun 2019 pemerintah perlu menyediakan total anggaran $\mathrm{Rp}$. 1,79 triliun hanya khusus untuk kebutuhan makanan. Ketiga, terjadi masalah seksual, kekerasan, kerusuhan, pembakaran dan puncaknya penghuni melarikan diri akibat petugas pengamanan kewalahan melaksanakan tugasnya karena beban kerja yang tidak sesuai dengan kapasitas dan cenderung melakukan kekerasan untuk memudahkan pengaturan penghuni (Novian et al., 2018).

Secara teoritik dapat dijelaskan bahwa situasi overcrowding dapat menimbulkan prisonisasi (prizonization). Sykes dengan "pains of imprisonment theory" mengatakan bahwa pada hakikatnya prisonisasi terbentuk sebagai respon terhadap masalah-masalah penyesuaian yang dimunculkan sebagai akibat pidana penjara itu sendiri dengan segala bentuk perampasan (deprivation). Penyesuaian di sini sebagai akibat perampasan. Perampasan di sini adalah hilangnya sesuatu yang biasanya dimiliki dan/atau dinikmati oleh orang-orang yang bebas, sehingga menimbulkan suatu penderitaan termasuk dalam hal ini adalah penderitaan harus berdesak-desakan di dalam Lapas/Rutan sebagai akibat dari over population (Angkasa, 2010).

Beberapa kasus yang terjadi selain over population dan lemahnya pengawasan dan penjagaan disinyalir pula 
karena tidak terjaminnya kebutuhan penghuni yang berujung pada frustasi, kecemasan atau keresahan bahkan terjadi kerusuhan disusul dengan penghuni melarikan diri, diantaranya: Pertama, Rutan Kelas II B Siak Sri Indrapura, Riau. Sejumlah tahanan dan napi kabur saat terjadi kericuan dan berujung pada pembakaran Rutan pada Sabtu 11 Mei 2019. Kericuan diduga dipicu pemukulan oleh petugas lapas terhadap seorang tahanan yang kedapatan memiliki narkotika jenis sabu. Kejadian tersebut memancing amarah narapidana dan tahanan lainnya hingga membakar Rutan tersebut. Menurut Kepala Kantor Wilayah Kemenkumhan Riau M. Diah dapat digambarkan bahwa kericuhan terjadi akibat overload melebihi $300 \%$ di mana seharusnya bangunan dihuni oleh 128 orang namun faktanya ditempati oleh 624 penghuni (Latifah, 2019).

Kedua, Kejadian serupa kembali terjadi hanya kurang dari sepekan yaitu tepatnya 16 Mei 2019 di Lembaga Pemasyarakatan Kelas III Langkat, Sumatera Utara. Penyebabnya sama dengan di Rutan Kelas II B Siak, akibat tidak terima diperlakukan kasar saat dirazia narkoba oleh petugas, para napi lantas mengejar petugas Lapas. Tak hanya itu ratusan napi menjebol bangunan dan membakar Lapas sekaligus kabur dari Lapas. Fakta yang sama ditemukan bahwa terjadi overload penghuni sebanyak 1.635 penghuni di mana kapasitas hanya 915 orang.

Pada dasarnya kondisi ini telah terdapat instrumen internasional yang mengenai Aturan Minimum Standar untuk Perawatan Tahanan, yaitu Nelson Mandela Rules, melarang perlakuan dan hukuman yang kejam, tidak manusiawi dan merendahkan martabat manusia bagi para tahanan dan napi yang berada dalam rutan/lapas, karena tahanan dan napi bermartabat dan tetap sebagai manusia (Rule No. 1, Nelson Mandela Rules). Oleh sebab itu, tahanan dan napi sedang dirampas kebebasannya di dalam rutan/lapas, hak-hak mereka yang lain tetap harus dipenuhi dan negara bertanggung jawab atas hal tersebut. Overcrowding di rutan/lapas tentu saja menyebabkan para tahanan dan napi tidak bisa mendapatkan hak-haknya yang tetap harus didapatkan selama mereka berada dalam rutan/lapas. Hal ini berpotensi terhadap pelanggaran HAM para tahanan dan napi selama mereka kehilangan hak atas kebebasannya (Latifah, 2019).

\section{B. Kebijakan Menangani Overcrowding di Indonesia pada Masa Pandemi Covid-19}

Pidana penjara dapat dikatakan telah menjadi "pidana dunia", artinya terdapat di seluruh dunia, termasuk Indonesia. Namun dalam perkembangannya banyak yang mempersoalkan kembali manfaat penggunaan pidana penjara dari dampak negatif perampasan kemerdekaan seseorang serta masalah overcrowding di rutan/lapasnya. Khususnya mengenai yang terakhir ini, malahan dikaitkan dengan merebaknya penyakit menular pandemi covid-19 yang menjangkiti bukan hanya Indonesia melainkan seluruh dunia. 
Kegagalan dalam menangani penyebaran covid-19 itu justru akan berisiko memicu bencana hak asasi manusia sehingga diperlukan usaha penyelamatan penghuni yang mudah terpapar covid-19 di tengah overcrowding. Hal ini disebut sebagai keadaan darurat oleh Komisaris Tinggi HAM PBB Michelle Bachelet yang dalam pernyataannya sekaligus merekomendasikan dan mendorong negara-negara $^{2}$ (Watch, 2020), guna memikirkan cara terbaik untuk mengeluarkan orang-orang yang dirampas kemerdekaannya, khususnya kalangan "prioritas" yang rentan terinfeksi covid19, misalnya: narapidana lanjut usia, narapidana yang sakit, narapidana yang berisiko rendah, narapidana perempuan, narapidana dengan disabilitas, narapidana anak-anak dan tahanan politik (Martha Ruth Thertina, 2020).

Patut dikemukakan, bahwa situasi overcrowding rutan/lapas ini sangat mendukung karakteristik dan mempercepat transmisi virus covid-19 dikarenakan beberapa faktor: Pertama, kondisi kebersihan rutan/lapas dengan belum memadainya penyediaan alat pembersih dan protokol kesehatan. Situasi ini mengikis martabat manusia dan

\footnotetext{
${ }^{2}$ Pendekatan internasional tersebut diterjemahkan oleh beberapa negara yang mengalami overcrowding untuk melakukan kebijakan diantaranya pembebasan bersyarat kepada narapidana karena pandemi covid-19, diantaranya Turki (100.000 orang), Iran (100.000 orang), Amerika Serikat (28.000 orang), Brazil (30.000 orang), India (50.000 orang), Thailand (8.000 orang), Filipina (38.822 orang). Sumber: https://www.hrw.org/news/2020/05/27/covid-19prisoner-releases-too-few-too-slow, diakses 30 Juni 2020.
}

merusakan kesehatan fisik, mental serta prospek pembinaan dan reintegrasi yang dapat menyebabkan kepanikan bagi penghuni karena takut tertular covid-19. Kedua, banyaknya jumlah penghuni di dalam fasilitas tertutup seperti sel (kamar) yang terlalu penuh dan sesak berisiko tinggi penularan karena tidak ada phisycal distancing. Ketiga, Potensi risiko penularan tidak saja antar penghuni, tetapi akan mudah menular pula ke petugas pengamanan dan para pengunjung, dan mereka berisiko akan menularkan ke keluarganya serta lingkungan tetangga dan kampung/desa. Artinya pembatasan fisik sosial menjadi gagal dan korbannya adalah warga masyarakat yang terkena covid-19 serta dapat menimbulkan claster baru.

Setelah mempertimbangkan rekomendasi PBB dan momentum memutus mata rantai penyebaran covid19, memberikan dorongan bagi suatu bangsa untuk mengambil kebijakan yang "abnormal" (Bergkamp, 2020) tak terkecuali di Indonesia. Masa pandemi covid-19 tentu memberikan pemerintah tanggung jawab atas ketertiban, keamanan, kenyamanan, dan kesejahteraan masyarakat. Tanggung jawab mana sebagaimana tertuang dalam alinea ke-IV UUD 1945 (Disantara, 2020), hal ini selanjutnya dimanifestasikan ke dalam salah satu usaha penanggulangan overcrowding dan pencegahan covid-19 ialah menggunakan pendekatan kebijakan pembebasan narapidana sebagai pemilihan dari berbagai alternatif yang tidak dapat 
dilepaskan dari pertimbangan rasional dan kebijaksanaan sesuai dengan keadaan dan perkembangan masyarakat. Kebijakan demikian, pada hakikatnya yaitu segala usaha yang rasional untuk tujuan bernegara (Arief, 2010). Namun demikian, kebijakan Pemerintah melalui Permenkumham No. 10 Tahun 2020 tentang Syarat Pemberian Asimilasi dan Hak Integrasi dalam Rangka Pencegahan dan Penanggulangan Penyebaran Covid$19{ }^{3}$ usaha inipun masih dipersoalkan. Permasalahannya ialah ada beberapa pihak yang menentang dan menilai kebijakan pengeluaran dan pembebasan narapidana tersebut sangat rentan kembali melakukan aksi kejahatan setelah dibebaskan. Dimana pemidanaan yang dilakukan saat ini lebih berorientasi kepada individu pelaku yang dipandang sebagai orang yang mampu untuk bertanggung jawab penuh atas perbuatan yang dilakukan maka sudah selayaknya dipidana (Susanti, 2019). Di sisi lain, usaha rasional untuk mengatasi "keadaan darurat" ini mempunyai kedudukan yang tidak kalah strateginya. Ia memegang posisi kunci yang harus diintensifkan dan diefektifkan.

Konsepsi kebijakan demikian, diintegralkan pula dengan ide kemanusiaan yang melandasinya, sebagaimana dijelaskan dalam konsideran

\footnotetext{
Sebenarnya di Indonesia telah memiliki instrumen hukum yang tertuang dalam Pasal 24 ayat (2) Permenkumham No. 33 Tahun 2015 tentang Pengamanan pada Lapas dan Rutan yang mengatur mengenai "keadaan tertentu" pada lapas/rutan jika terjadi pemberontakan, kebakaran, bencana alam dan/atau penyerangan dari luar namun tidak termasuk ketika terjadi bencana non alam berupa wabah atau pandemi.
}

bahwa: (a) Lembaga Pemasyarakatan, Lembaga Pembinaan Khusus Anak, dan Rumah Tahanan Negara merupakan sebuah institusi tertutup yang memiliki tingkat hunian tinggi, sangat rentan terhadap penyebaran dan penularan Covid-19; (b) Covid-19 telah ditetapkan sebagai bencana nasional non-alam, perlu dilakukan langkah cepat sebagai upaya penyelamatan terhadap tahanan dan warga binaan pemasyarakatan yang berada di Lembaga Pemasyarakatan, Lembaga Pembinaan Khusus Anak, dan Rumah Tahanan Negara (c) untuk melakukan upaya penyelamatan terhadap narapidana dan anak yang berada di Lembaga Pemasyarakatan, Lembaga Pembinaan Khusus Anak, dan Rumah Tahanan Negara, perlu dilakukan pengeluaran dan pembebasan melalui asimilasi dan integrasi untuk pencegahan dan penanggulangan penyebaran Covid-19.

Di samping itu, di lihat dari tujuan pemidanaan akan sulit tercapai apabila dilakukan pembiaran narapidana yang karena kondisi rutan/lapas telah overcrowding, dan menjadikan narapidana menjadi sangat rentan dapat terinfeksi virus covid-19. Setidaknya tujuan untuk pembinaan dan pembimbingan narapidana agar menjadi orang yang baik dan berguna tidak akan pernah tercapai. Dengan potensinya yang dapat menyebabkan kematian massal, maka bila masuk ke lapas/rutan maka pembiarannya akan merendahkan martabat narapidana sebagai manusia. Terjadi overcrowding saja sudah tidak manusiawi, apalagi bila rutan/lapas 
berubah menjadi kuburan massal akibat wabah covid-19 (Setyowati, 2020).

Bersesuaian dengan tujuan pemidanaan, sistem pemasyarakatan yang ada saat ini adalah rangkaian penegakan hukum yang bertujuan agar warga binaannya menyadari kesalahannya, memperbaiki diri, dan tidak mengulangi tindak pidana sehingga dapat diterima kembali oleh lingkungan masyarakat, dapat aktif berperan dalam pembangunan, dan dapat hidup secara wajar sebagai warga yang baik dan bertanggung jawab. Itu sebabnya sudah tepat bila narapidana disebut sebagai "warga binaan". Apabila tidak ada upaya yang cukup untuk melakukan pencegahan penularan covid19, maka narapidana bukan lagi warga binaan tetapi menjadi warga pembinasaan. Lagi pula apabila ada pembiaran maka akan dapat dianggap penambahan hukuman bagi narapidana (overpunishment), hukuman penjara yang sedang dijalaninya seakan-akan ditambah dengan hukuman psikologis berupa teror penyakit dan kematian (Setyowati, 2020).

Bertolak dari pemikiran tersebut, pemberian asimilasi atau integrasi (bebas bersyarat, cuti bersyarat, dan cuti menjelang pembebasan) adalah dua program penting dalam pembinaan narapidana. Program ini mempunyai prosedur ketat dan intinya berlaku untuk narapidana yang berkelakuan baik di dalam lapas. Kedua program ini adalah hak narapidana, hak mana dapat dibatasi (dengan syarat) atau dikurangi (sebagian), namun tidak dapat dihapus sama sekali bagi seorang narapidana. Kedua hak ini juga merupakan bantuan manajemen lapas, karena dengan adanya hal tersebut, maka narapidana akan mempunyai motivasi dan insentif untuk menaati aturan tata-tertib dalam lapas dan hal ini membantu para petugas di lapas bersangkutan.

Menurut Menkumham Yasonna $\mathrm{H}$. Laoly, dari total data dikumpulkan ada 40.026 narapidana dewasa dan anak telah dikeluarkan melalui program asimilasi dan integrasi di seluruh Indonesia dalam rangka pencegahan penyebaran covid-19. Dengan rincian asimilasi narapidana sebanyak 36.681 dan anak binaan sebanyak 940 orang. Sementara narapidana yang bebas melalui integrasi sebanyak 2.362 dan anak binaan sebanyak 43 orang. Dari segi anggaran, pelepasan narapidana mendorong penghematan negara sebanyak Rp. 348 milyar (Laoly, 2020). Artinya pengurangan jumlah penghuni selain mengurangi beban keuangan negara sekaligus berdampak pada presentasi overcrowding nasional per 29 Februari 2020 dari $102 \%$ menyusut kurang dari $74 \%$ tingkat overcrowding per 19 Juni 2020, atau dari 268.922 menjadi $228.896 \quad$ penghuni $^{4}$ (Pemasyarakatan, 2020a).

Pemberian asimilasi dan integrasi sendiri dilaksanakan di rumah dengan pembimbingan dan pengawasan Balai Pemasyarakatan (BAPAS) dengan memperhatikan tahap perilaku narapidana serta telah menjalani $1 / 2$ (satu per dua)

\footnotetext{
${ }^{4}$ Sistem Database Pemasyarakatan (SDP), Dirjen Pemasyarakatan, data yang diolah adalah perbandingan data sebelum covid-19 dan pada saat pandemi covid-19 per 19 Juni 2020.
} 
masa pidana untuk asimilasi. Sedangkan integrasi selain berkelakuan baik minimal telah menjalani masa pidana 2/3 (dua per tiga) dengan masa pidana paling sedikit 9 bulan. Artinya pemberian asimilasi dan integrasi bukanlah kebebasan yang sebebas-bebasnya melainkan tetap diberi pembimbingan dan pengawasan sebagaimana tertuang dalam Pasal 2, Pasal 9 dan Pasal 19 Permenkumhan No. 10 Tahun 2020, hal mana identik dengan karantina mandiri (perampasan kemerdekaan mandiri) di rumah dalam jangka waktu tertentu bagi mereka yang mendapatkan fasilitas ini.

Perlu ditegaskan, bahwa dalam penerapannya program asimilasi dan integrasi ini masih sangat terbatas dan tidak berlaku pada semua jenis kejahatan. Adapun pengecualiannya untuk narapidana kejahatan tertentu seperti terorisme, narkotika, korupsi, dan kejahatan berat lainnya serta terhadap pelaku warga negara asing. Sedangkan di sisi lain, bila dilihat dari data jumlah penghuni didasarkan pada jenis tindak pidana (kejahatan) yang dilakukan ditemukan kenyataan bahwa justru tindak pidana narkotika sebagai penyumbang terbesar terjadinya overcrowding sebesar 119.341 orang, diikuti tindak pidana umum sebesar 103.513 orang, tindak pidana korupsi 4.371 orang, terorisme 527 orang, human trafficking 315 orang, illegal logging 197 orang, serta money laundering 161 orang (Pemasyarakatan, 2020a). Dengan tidak terakomodasinya narapidana narkotika mengakibatkan kebijakan mengatasi overcrowding belum berjalan maksimal. Hal ini, senada dengan pernyataan Yasonna $H$. Laoly bahwa, belum adanya kejelasan dalam UU Narkotika mengenai pengklasifikasian korban, pengguna, pengedar/kurir, dan bandar menjadi kendala dalam penanganan narapidana tindak pidana narkotika, termasuk dalam kebijakan pembebasan di masa pandemi covid-19 (Laoly, 2020).

Pembatasan yang demikian, sasaran dari kebijakan ini pun pada dasarnya tidak ditunjukkan semata-mata kepada semua penghuni termasuk narapidana lanjut usia, narapidana rentan penyakit, dan narapidana disabilitas. Menurut Romli Atmasasmita, kebijakan pemerintah yang demikian sangatlah diskriminatif karena penyebaran covid-19 tidak melihat status narapidana, baik tindak pidana umum, korupsi, terorisme, narkotika sama-sama berpeluang terserang virus tersebut. Baginya, terdapat banyak narapidana baik terorisme maupun korupsi yang sudah berusia sepuh dan memiliki riwayat kesehatan kurang bagus. Sehingga dalam situasi demikian, pembatasan tersebut harus dikesampingkan (Setyowati, 2020).

Wajar apabila kebijakan ini pada akhirnya mengakibatkan polemik di tengah masyarakat, menimbulkan sekat pro dan kontra. Sementara sebagian menolak sama sekali dan sebagian lainnya menyetujui dengan atau tanpa pembatasan. Patut pula sebagai perhatian, terkait kekhawatiran pembebasan narapidana terlepas dalam kapasitasnya sebagai recidive atau tidak, perlu diantisipasi faktor kriminogen narapidana 
asimilasi dan integrasi: Pertama, terkait dengan karakter masing-masing individu yang berpotensi besar mengulangi perbuatannya. Namun, yang menjadi sorotan adalah soal hukuman penjara yang tidak bisa merubah karakter mereka untuk hidup lebih baik di masyarakat. Kedua, yakni berkaitan dengan situasi yang serba sulit ini, di saat pandemi covid-19, mereka kesulitan mencari pekerjaan yang layak. Hal itu pun diperburuk dengan pandangan negatif masyarakat soal narapidana. Ketiga, menyangkut segi keadilan terutama dari pihak korban. Korban yang melihat eks narapidana memperoleh perlakukan yang dapat melukai rasa keadilan (Sugema, 2020).

Kekhawatirkan di atas, patut dikemukakan dari data yang diperoleh dari jumlah 40.026 narapidana asimilasi dan integrasi yang kembali melakukan tindak pidana diangka 222 orang atau hanya sebesar 0,6\%, (Puspita, 2020) tingkat residivis ini tergolong rendah dan dalam batas terkendali. Terlepas dari hal tersebut, bahwa usaha pemerintah sudah selayaknya diapresiasi sebagai upaya dalam rangka menyelamatkan narapidana menghadapi covid-19 sebagai bencana nasional non alam. Lapas/Rutan dan Lembaga Pembinaan Khusus Anak sebagai closed institution yang mengalami over population jelas sangat rentan terhadap transmisi covid-19. Meskipun, pemberian program asimilasi dan integrasi dengan pembatasan tertentu di tengah wabah covid-19 yang masih berlangsung sesungguhnya belum dapat dikatakan efektif dalam mengatasi overcrowding, karena sekalipun kebijakan ini bagaikan hujan ditengah kegersangan serta selintas mengurangi dan memberikan kelonggaran pada rutan/lapas namun situasi over population masih tetap berlangsung.

\section{SIMPULAN}

Kesimpulan Rutan/lapas di Indonesia berada dalam situasi yang mengkhawatirkan karena masuk kategori overcrowding. Situasi overcrowding pada rutan/lapas di Indonesia per 31 Februari di atas $102 \%$. Jika tolak ukur situasi kepadatan digambarkan dengan menggunakan occupancy rate (jumlah tahanan per kapasitas hunian), maka termasuk kategori overcrowding atau occupancy rate di atas 100\%. Dari total 33 Kanwil Kemenkumham yang tersebar di seluruh provinsi di Indonesia, hanya 4 wilayah yang tidak mengalami overcrowding, sedangkan 29 wilayah lainnya mengalami overcrowding baik dalam tingkatan (overcrowding, critical overcrowding bahkan sampai extreme overcrowding). Kondisi mana akan berdampak pada kegagalan tujuan pembinaan melalui pendidikan, rehabilitasi, dan reintegrasi. Sewaktu terjadi overcrowding yang penuh dan sesak saja sudah tidak manusiawi, apalagi bila hal ini di tengah bencana nasional non alam wabah covid-19. Untuk menghindari rutan/lapas berubah menjadi kuburan massal akibat pandemi sekaligus mengatasi overcrowding, ditempuhlah kebijakan melalui asimilasi dan hak integrasi ditujukan kepada narapidana 
sebanyak 40.026 orang, sehingga berdampak pada penurunan tingkat overcrowding nasional dari $102 \%$ ke angka kurang dari $74 \%$ data per 19 Juni 2020, dengan tingkat pengulangan kejahatan narapidana asimilasi dan integrasi yang tergolong rendah diangka $0,6 \%$ atau setara 222 orang. Kebijakan demikian pun, perlu diapresiasi namun masih sulit untuk dikatakan efektif apalagi di sisi lain hanya terbatas terhadap kejahatan tertentu sedangkan bagi narapidana kejahatan narkotika, terorisme, korupsi dan sebagainya tidak mendapatkan fasilitas ini, hal mana berujung pada kelonggaran di rutan/lapas namun situasi over population tetap berlangsung. Kedepan diperlukan reformasi kebijakan pidana secara komprehensif atau langkah strategis lainnya diantaranya: Pertama, perlunya kejelasan regulasi mengenai "keadaan tertentu" yang meliputi baik bencana alam maupun non alam. Kedua, perlunya ditinjau kembali berkaitan dengan persoalan dekriminalisasi, penalisasi, diversi, alternatif penahahan pra persidangan serta alternatif pidana penjara seperti pidana mandiri di rumah (karantina mandiri) bahkan upaya menghilangkan faktor-faktor yang dapat menyebabkan narapidana berbuat hal-hal yang bertentangan dengan hukum, kesusilaan, agama, atau kewajibankewajiban sosial lain yang dapat dikenakan pidana.

\section{DAFTAR PUSTAKA}

Alin, F. (2017). Sistem Pidana dan Pemidanaan di dalam Pembaharuan Hukum Pidana Indonesia. $\mathrm{JCH}$
(Jurnal Cendekia Hukum), 3(1), 1431.

Angkasa, A. (2010). Over Capacity Narapidana Di Lembaga Pemasyarakatan, Faktor Penyebab, Implikasi Negatif, Serta Solusi Dalam Upaya Optimalisasi Pembinaan Narapidana. Jurnal Dinamika Hukum, 10(3), 212-219.

Arief, B. N. (2010). Kebijakan legislatif dalam penanggulangan kejahatan dengan pidana penjara. Badan Penerbit, Genta Publishing.

Bergkamp, L. (2020). State liability for failure to control the COVID-19 epidemic: international and dutch law. European Journal of Risk Regulation, 11(2), 343-349.

Disantara, F. P. (2020). TANGGUNG JAWAB NEGARA DALAM MASA PANDEMI COVID-19. JCH (Jurnal Cendekia Hukum), 6(1), 48-60.

Laoly, Y. H. (2020). "Kebijakan Pembebasan Narapidana, Webinar "Kebijakan Narapidana.

Latifah, M. (2019). Overcrowded pada Rumah Tahanan dan Lembaga Pemasyarakatan di Indonesia: Dampak dan Solusinya. Badan Hukum Info Singkat Kajian Terhadap Isu Aktual Dan Strategis, XI(10), 2.

Martha Ruth Thertina. (2020). Kebijakan Penjara-penjara Dunia di Tengah Pandemi Corona. Katadata. Retrieved from https://katadata.co.id/marthathertina/ berita/5e9a41f57bfeb/kebijakanpenjara-penjara-dunia-di-tengahpandemi-corona. Diakses tanggal 30 Juni 2020.

Novian, R., Eddyono, S. W., Kamilah, A. G., Dirga, S., Nathania, C., Napitupulu, E. A. T., ... Budhiman, A. A. (2018). Strategi Menangani 
Overcrowding di Indonesia: Penyebab, Dampak dan Penyelesaiannya. Diedit oleh Zainal; Anggara Abidin. Pertama. Institute for Criminal Justice Reform (ICJR).

Pemasyarakatan, D. P. (2020a). Database Sistem Pemasyarakatan (DSP), diakses 19 Juni 2020.

Pemasyarakatan, D. P. (2020b). Database Sistem Pemasyarakatan (DSP), diakses 29 Februari 2020.

Puspita, R. (2020). Menkumham: 222 Orang Napi Asimilasi dan Integrasi Berulah. Republika. Retrieved from https://republika.co.id/berita/qcbwa5 428/menkumham-222-orang-napiasimilasi-dan-integrasi-berulah. Diakses tanggal 30 Juni 2020.

Setyowati, D. (2020). Memutus Rantai Penyebaran Covid-19: Efektifitas Peraturan Perundang-Undangan Vs Pengeluaran \& Pembebasan Narapidana di Masa Pandemi.

Sudarto. (2010). Kapita Selekta Hukum Pidana. Bandung: Alumni.
Sugema, J. A. (2020). PENANGANAN OVER KAPASITAS DI DALAM LAPAS. JUSTITIA: Jurnal Ilmu Hukum Dan Humaniora, 7(1), 201208.

Susanti, D. E. (2019). Pemidanaan terhadap Anak sebagai Pelaku Tindak Pidana Studi Kasus Perkara Pidana No. 07/pid-sus-anak/2017/pn. pdg. JCH (Jurnal Cendekia Hukum), 4(2), 187-206.

Watch, H. R. (2020, May 27). Covid-19 Prisoner Releases Too Few, Too Slow. Retrieved from https://www.hrw.org/news/2020/05/2 7/covid-19-prisoner-releases-toofew-too-slow. Diakses tanggal 30 Juni 2020.

WHO. (2020). Novel Coronavirus. Retrieved from https://www.who.int/indonesia/news/ novel-coronavirus/qa/qa-for-public. Diakses tanggal 30 Juni 2020. 